\title{
Higher Education Tuition Standard Model Analysis
}

\author{
Dongping Wang \\ School of Economics, Tianjin Polytechnic University \\ Tianjin 300160, China \\ E-mail: hebeimt@sohu.com
}

Tao Ma

School of Economics, Tianjin Polytechnic University

Tianjin 300160, China

E-mail: hebeimt@sohu.com

Fund: The national educational science "Eleventh Five-Year Plan" object (NO.DGA080073)

\begin{abstract}
Reform of higher education tuition in China is an important aspect of the reform of higher education and a problem which is urgent need to solve from "elite education" to "public education". "pay tuition to study ", "who invests ,Who benefits " have become a society-wide consensus. This paper mainly examines the impact of the average education cost, school level, advantages of location and school categories on university tuition fees, we set up the planning model with the analytic hierarchy process and quantitative analysis method .we focus on a national key university in Beijing and an ordinary university in Hebei province to analysis their tuitions which selected from 606colleges and universities of china.
\end{abstract}

Keywords: Charge differently, Quantitative analysis, AHP, Higher Education

The reasonableness of higher education tuition fees has been widespread concerned and studied. The proportion of higher education student tuition fees that accounts for the education costs and the proportion of higher education tuition fees that accounts for the average annual income of the family should remain at what level can we guarantee the quality of universities teaching and not give a heavy burden to most family?

The determination of higher education tuition fees in higher education is based on a certain amount of information .there are many factors that affect the higher education fees, such as average student training costs, the average annual household income, university type, the location of university and economic status, university level, the state funding, personal expected return, etc. However those data are incomplete and those indicators are different, so we make a number of appropriate methods in this paper to collect and deal with these information. For example, when we deal with the data of average student training costs, we reform the range standardization method to quantify the data between 0.5 and 1 .

Firstly, Data collection and extraction. We get those related data such as average student training costs, the state financial allocations, the average annual household income data from China Statistical Yearbook and China Educational Finance Statistical Yearbook. At the same time we search related websites and books to obtain information on university category, the location of school and economics. And we extract and collate data with Excel, LINGO, SPSS software.

Secondly, Making a model. We transform the problem about the higher education reasonable tuition fees into a problem to maximize the quality of education which is bound by the residents' ability to pay for tuition. Among them, there are many factors to affect the number of tuition fees, we should quantify these factors and make a non-dimensional analysis, using AHP to determine the weights of various factors, to ensure the highest number of tuition fees is not more than $15 \%$ of the average household income. We take the average of standardized values of all the higher education tuition fees as tuition standard, therefore to work out the tuition Fees of all the universities. Tuition fees for higher education 
should be based on urban residents' and rural residents' affordability of households to pay, and to ensure their commitment to the tuition fees is equal.

Thirdly, the western region lags far behind the eastern region economically. For example, in 2007, Shanghai, Beijing, Zhejiang's urban residents' disposable income per capita reached 23623, 21989 and 20574 Yuan, but Gansu, Heilongiiang, Qinghai reached only 10012, 10245 and 10276 Yuan. The gap between them is so wide. Shanghai, Beijing, Tianjin's per capita net income of rural residents reached 10222, 9559 and 8752 Yuan, but Gansu, Guizhou, Yunnan's per capita net income of rural residents is only 2328,2374 and 2634 Yuan. Shanghai, Beijing, Tianjin's per capita net income of rural residents is 4 times as many as Gansu, Guizhou, Yunnan's. In order to better reflect the education fair, we set up model II to determine the different tuition fees according to the level of economic development of different regions.

\section{Model assumptions and symbol system}

\subsection{Model assumptions}

1) The proportion that higher education tuition fees account for the average cost of education and training is not more than $25 \%$;

2) The proportion that higher education tuition fees account for the overall household income should be maintained within $15 \%$;

3) In this paper, the model only researches the undergraduate course school that arranged before 606 in "Evaluation of the 2008 Chinese University Study";

4) Different charge in higher education, namely, urban and rural college students in accordance with its proportion of household income to pay the tuition fees, insisting the principle of fairness in education;

5) The model is improved that different charge in higher education is double different fees, that is urban and rural college students pay the tuition fees in accordance with its proportion of household income, and charge different tuition fees in different provinces, to insist the principle of fairness in education;

6) The average population in urban family is 3 , and the average rural family is 4 .

\subsection{Symbol system}

BK: National Financial allocations;

YQ: the expected return of individual students;

$\mathrm{R}$ : the proportion that urban families accounted for rural families;

a: the proportion that higher education tuition fees accounted for the average of every student's training costs;

b: the proportion that higher education tuition fees accounted for the family income;

AC: the average training costs of national higher education students;

CR: the rural per capita income;

UR: the urban per capita income;

Fi: the standardized scoring value of No.i school's tuition;

Ei: the tuition that No.i school charge;

K: school category;

Fimax: the maximum value of all researched academy's standardized scoring value;

C: the average training costs of every student;

L: location advantages;

AF: the standardized scoring value of all academies" tuition;

T: university level;

CAF: the corresponding tuition of AF, namely, the average tuition of students;

$\mathrm{CC} \mathrm{j}$ : the tuition that the No. $\mathrm{j}$ province's rural college student paid;

$\mathrm{UC} \mathrm{j}$ : the tuition that the No. $\mathrm{j}$ province's urban college student paid

\section{Setting up model}

\subsection{Data collection and analysis}

The standards of higher education depends primarily on the average training cost of students, university category, 
location advantages, university level and the average household income. Therefore, to solve these problems, we should search the related data and conduct an in-depth analysis. The main data collection is as follows:

1) The average training cost of university students in all regions

Predicting the average training cost of university students in all regions in 2008, it affects actual value of the 2008 when the year is closer, therefore, followed by five years of data from the weight value for $0.1,0.15,0.2,0.25,0.3$. We use software to predict the average training cost of university students in all regions in 2008.

Standardized the average training cost of university students in 2008: the improvement of range standardization.

According to the initial model, the greater the average training cost is, the higher charging standards are. The improvement of range standardization is as follows:

$X_{\max }=32715$ (Beijing), $X_{\min }=8171$ (Guizhou Province)

\begin{tabular}{|l|l|l|l|l|l|l|l|}
\hline Region & 2003 & 2004 & 2005 & 2006 & 2007 & $\begin{array}{l}\text { Prediction } \\
\text { of 2008 }\end{array}$ & $\begin{array}{l}\text { standardization } \\
\text { value of 2008 }\end{array}$ \\
\hline Beijing & 32104 & 30823 & 30634 & 33592 & 34151 & 32715 & 1.00 \\
\hline Hebei & 11574 & 11093 & 10612 & 10239 & 10152 & 10452 & 0.55 \\
\hline
\end{tabular}

Data source: Based on China Educational Finance Statistical Yearbook from 2004 to 2008.

2) The level of university

According to the undergraduate course school that arranged before 606 in "Evaluation of the 2008 Chinese University Study", we standardize the rank of the college. Because the comprehensive strength of the top 100 schools in the rank is basically in accordance with the linear relationship between the decline and relatively large gap, so the top 100 schools are divided into 10 groups. As for, the 101-300 schools' gap is a little smaller, so select the class width is 20 and also divided into 10 groups. The gap of the last 306 schools' comprehensive strength is small, in order to show the otherness, we divide them into 10 groups and select the class width generally is 30 .

Ways to assign ranks to the universities of standardized treatment, standardization formula is:

$\beta_{i}=\cos \left(\frac{\pi}{90} * x\right)$

Considering the ranking, total score, science research, personnel training and comprehensive reputation of the 606 colleges and universities, which have a great impact for the level of running a school, averaging the standardization of the five factors for the comprehensive level of running a school, then receive the standardized value of the level of university. The data of a national key university in Beijing and an ordinary university in Hebei province are as follows:

\begin{tabular}{|l|l|l|l|l|l|l|}
\hline Rank & University & total score & $\begin{array}{l}\text { science } \\
\text { research }\end{array}$ & $\begin{array}{l}\text { personnel } \\
\text { training }\end{array}$ & $\begin{array}{l}\text { comprehensive } \\
\text { reputation }\end{array}$ & Result \\
\hline 2 & $\begin{array}{l}\text { A national key university } \\
\text { in Beijing }\end{array}$ & 96.09 & 100.00 & 88.53 & 93.03 & 0.978 \\
\hline 128 & $\begin{array}{l}\text { An ordinary university in } \\
\text { Hebei province }\end{array}$ & 3.02 & 1.56 & 3.06 & 12.52 & 0.603 \\
\hline
\end{tabular}

\section{3) School category}

For the type of colleges, we mainly consider 985, 211, provincial priorities and the Provincial ordinary university. For these four categories of schools is assigned to the standardization, valuing the 985 institutions for 4, 211 engineering colleges' assignment for 3 , valuing the provincial priorities for the 2, and Provincial ordinary university for the 1 . Take into account in the evaluation of students at colleges and universities, institutions of higher learning category for its gently diminishing the effectiveness of first and subsequently decreasing faster. Its membership functions as follows:

$\phi(x)=\left\{\begin{array}{l}0, x \leq 1 \\ \frac{3}{4}+\frac{1}{4} * \sin \frac{\pi}{4}(x-2), 1<x \leq 4 \\ 1, \quad x>4\end{array}\right.$

This function can through the colleges and universities to standardize the type of treatment and the values in $[0.5,1]$ interval. School standardized values of the categories are as follows: 


\begin{tabular}{|l|l|l|l|l|}
\hline School category & 985 & 211 & Provincial key university & Provincial ordinary university \\
\hline$\phi_{i}$ & 1 & 0.97 & 0.75 & 0.57 \\
\hline
\end{tabular}

4) Regional advantage

The regional advantage of colleges and universities main to consider the geographical location of the advantage and disadvantage of various provinces and cities, as well as the level of economic development (per capita GDP) factors. The regional advantage has both economic factors and geographical factors. Therefore, we consider the per capita GDP of various provinces and cities as studying the level of economic development indicators, provinces and cities to maintain a relatively constant level of per capita GDP basis in the $[0.5,1]$ interval on standardization.

$$
\gamma=0.5+0.5 * \frac{x-x_{\min }}{x_{\text {max }}-x_{\min }}
$$

Refer to traditional Chinese geographical classification of the various provinces and cities, the country is divided into nine areas: Beijing and Shanghai, Tianjin and Guangzhou, East China, Central China, North China, Northeast, Southwest, South China, Northwest. Various provinces and cities in the standardization of the specific geographical location in the following table:

\begin{tabular}{|l|l|l|l|l|l|}
\hline & $\begin{array}{l}\text { Standardization } \\
\text { value }\end{array}$ & $\begin{array}{l}\text { Province } \\
\text { and city }\end{array}$ & $\begin{array}{l}\text { Standardization } \\
\text { value }\end{array}$ & Province and city \\
\hline $\begin{array}{l}\text { Beijing, } \\
\text { Shanghai }\end{array}$ & 1 & $\begin{array}{l}\text { Beijing, } \\
\text { Shanghai }\end{array}$ & northeast & 0.7 & $\begin{array}{l}\text { Heilongiang, } \\
\text { Jilin, } \\
\text { Liaoning }\end{array}$ \\
\hline $\begin{array}{l}\text { Tianjin, } \\
\text { Guangzhou }\end{array}$ & 0.9 & $\begin{array}{l}\text { Tianjin } \\
\text { Guangzhou }\end{array}$ & southwest & 0.65 & $\begin{array}{l}\text { Chuan, Gui, Yun, } \\
\text { Zang, Yu }\end{array}$ \\
\hline East China & 0.85 & $\begin{array}{l}\text { Su, Zhe, Lu, } \\
\text { Min, Wan, } \\
\text { Gan }\end{array}$ & $\begin{array}{l}\text { south } \\
\text { China }\end{array}$ & 0.6 & Qiong, Gui \\
\hline North China & 0.75 & Jin, Meng, Ji & northwest & 0.5 & $\begin{array}{l}\text { Shan, Gan, Ning, } \\
\text { Xin, Qing }\end{array}$ \\
\hline
\end{tabular}

Because of the level of economic development for regional advantage is greater than the impact of geographical location, may wish to check the proportion of $6: 4$, the composite calculated advantage of the standardized values. The data of a national key university in Beijing, an ordinary university in Hebei province are as follows:

\begin{tabular}{|l|l|l|l|l|l|}
\hline university & region & $\begin{array}{l}\text { standardized } \\
\text { values of } \\
\text { location } \\
\text { advantage }\end{array}$ & university & region & $\begin{array}{l}\text { standardized } \\
\text { values of } \\
\text { location } \\
\text { advantage }\end{array}$ \\
\hline $\begin{array}{l}\text { A national key } \\
\text { university in } \\
\text { Beijing }\end{array}$ & Beijing & 0.959 & $\begin{array}{l}\text { An ordinary } \\
\text { university in Hebei } \\
\text { province }\end{array}$ & Hebei & 0.664 \\
\hline
\end{tabular}

\subsection{Setting up Model}

Generally speaking the higher education tuition fees should not exceed $15 \%$ of the total household income, in order to ensure the quality of teaching, the school should raise adequate funding for teaching.

\subsubsection{Analysis of setting up model}

1) firstly, we consider the objective function max $\mathrm{Ei}=\mathrm{Fi} / \mathrm{AF} * \mathrm{AC} * \mathrm{ai}$, namely, after solving Fi, we get the maximum of ai, the objective function is that max ai.

2) then considering the constraint conditions

(1) the bound of tuition fees accounted for the proportion of the training costs: $\mathrm{a}_{\mathrm{i}}<=25 \%$.

National provides that university tuition fees accounted for the proportion of the training costs in general should not exceed $25 \%$, 
(2) tuition fees accounted for the proportion of total household income constraint: $b_{i}<=15 \%$.

the family affordability of tuition fees generally accounted for total household income does not exceed $15 \%$.

(3)various colleges and universities should not exceed the maximum charge capacity of the residents

$\frac{C A F^{*} F_{i \max }}{A F} \leq \frac{C R^{*} 4+U R * 3 R}{R+1} * 0.15$

Suggesting the planning model as follows:

$$
\left\{\begin{array}{l}
\max E_{i}=\frac{F_{i}}{A F} * A C^{*} a \\
\mathrm{a}_{\mathrm{i}} \leq 25 \% \\
\mathrm{~b}_{\mathrm{i}} \leq 15 \% \\
\frac{C A F^{*} F_{i \max }}{A F} \leq \frac{C R^{*} 4+U R^{*} 3 R}{R+1} * 0.15
\end{array}\right.
$$

\section{Model Solution}

\subsection{Solving method}

In the target function, the standardized value of the tuition fees of colleges and universities (Fi) are unknown. The factors that affect Standardized value of tuition fees are the average training cost of university student $\mathrm{C}$, university Type K, the advantage of location L and university level T. We can use the data of Annex 1and Annex 2 to determine standardized number of the tuition fees of colleges and universities Fi with analytical hierarchy process.

\subsection{The determination of the standardized value of tuition fees}

The raw data of the factors that affect composite scores are Di, In the front we have already standardized the average training cost of university student $\mathrm{C}$, university Type $\mathrm{K}$, the advantage of location L and university level T. Using AHP method that bases on the index level of analysis to determine each university's total score. we set up the goal hierarchy in order to obtain the score of each university, as shown in Figure 1, the top layer is the target layer, middle layer is a criterion, the bottom layer is the program layer.

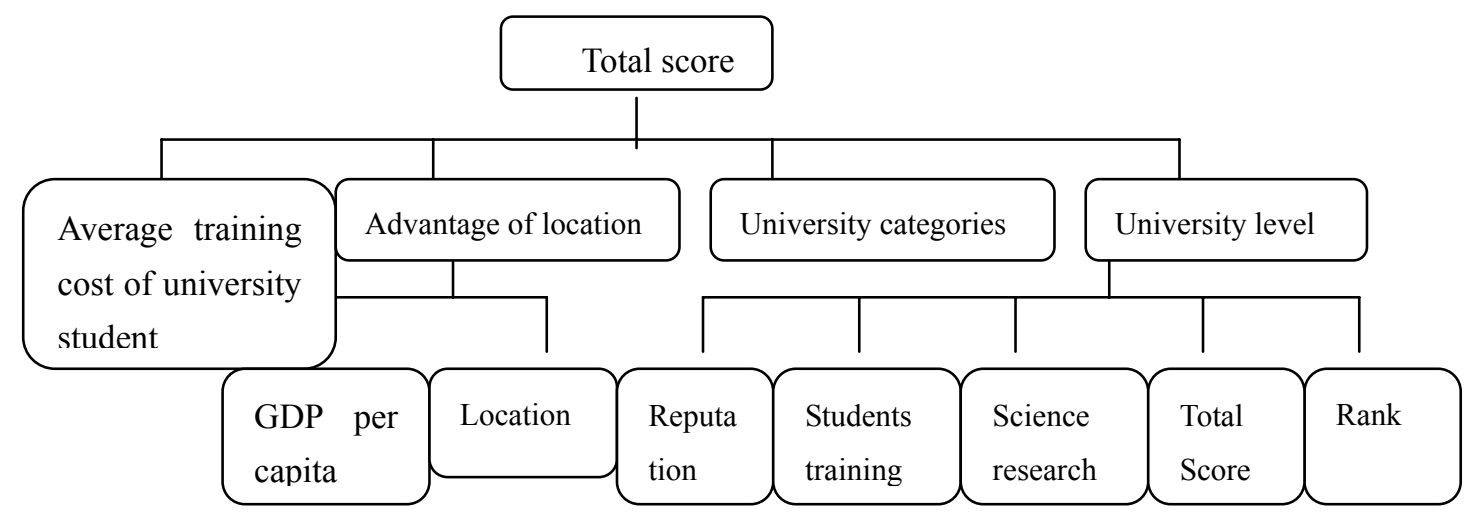

The indicators is better than the traditional 1-9 scale, it overcomes the short-coming that its coherence is not equivalent with mind coherence and it is in accordance with the transfer guidelines, meanwhile the gap should not be too much between each factors. Checking the relative importance $\mathrm{a}=1.618$, the meaning of scaling index is as follows:

\begin{tabular}{|l|l|l|l|}
\hline Scale aij & Scaling definition & Scale aij & Scaling definition \\
\hline $\mathrm{a} 0=1$ & Di is as important as Dj & $\mathrm{a} 3=4.236$ & Di is important than Dj obviously \\
\hline $\mathrm{a} 1=1.618$ & Di is slightly important than $\mathrm{Dj}$ & $\mathrm{a} 4=6.854$ & Di is very important compared to Dj \\
\hline $\mathrm{a} 2=2.618$ & Di is important than Dj & $\mathrm{a} 5=11.09$ & Di is absolutely essential compared with Dj \\
\hline
\end{tabular}

Determining the matrix structure. Taking into account scoring, various factors on the impacts of tuition fees are not too big, so the weight of each factor should not be great different. In this paper, subjective judgments resulting matrix is as follows: 


$$
A=\left(a_{i j}\right)_{4^{*}}=\left(\begin{array}{cccc}
1 & a & a^{2} & a^{2} \\
a^{-1} & 1 & a^{2} & a^{2} \\
a^{-2} & a^{-2} & 1 & a \\
a^{-2} & a^{-2} & a^{-1} & 1
\end{array}\right)
$$

We deal with the above-mentioned matrix with Mathematica program and make the consistency test. Obtaining the largest eigenvalue of matrix $\mathrm{A}$ is 4.015 , consistency index $\mathrm{CI}=0.0194$ and consistency ratios $\mathrm{CR}=\mathrm{CI} / \mathrm{RI}=0.022<0.1$, so $\mathrm{CR}=0.022$, their subjective judgments matrix pass the consistency test. Simultaneously we can get weight values of various factors are $0.405,0.318,0.155,0.122$.Further we can get the cost scores of university $\mathrm{i}$ :

$$
F_{i}=\sum_{j=1}^{4} w_{j} \times q_{i j},(i=1,2, \ldots, 606, j=1,2,3,4) ;
$$

$\mathrm{q}_{\mathrm{ij}}$ is stand for the standardization value of university I's factor J. The standardized values of National key universities in Beijing and an ordinary university in Hebei Province are as follows:

\begin{tabular}{|l|l|l|l|l|l|}
\hline Rank & university & $\begin{array}{l}\text { Tuition } \\
\text { score }\end{array}$ & Rank & university & $\begin{array}{l}\text { Tuition } \\
\text { score }\end{array}$ \\
\hline 2 & $\begin{array}{l}\text { National key universities in } \\
\text { Beijing }\end{array}$ & 0.991 & 174 & $\begin{array}{l}\text { an ordinary university in Hebei } \\
\text { Province }\end{array}$ & 0.703 \\
\hline
\end{tabular}

\subsection{Model Solution}

Fi is the standardized value of each university tuition fees we get from the above-mentioned solution. We substitute Fi into the above model and solve with LINGO 11.0. We can get the data of National key universities in Beijing and an ordinary university in Hebei province based on the results:

\begin{tabular}{|l|l|l|l|l|}
\hline Name of universities & The weighted average fees & The value of B & urban & rural \\
\hline $\begin{array}{l}\text { A national key university in } \\
\text { Beijing }\end{array}$ & 4406 & 0.150 & 6191 & 2479 \\
\hline $\begin{array}{l}\text { An ordinary college in } \\
\text { Hebei province }\end{array}$ & 2819 & 0.096 & 3961 & 1586 \\
\hline
\end{tabular}

\section{Model improvement}

When we solve the original model we find that the proportions of university tuition fees account for urban and rural household income are same. Meanwhile Peking University chare the highest tuition fees accounted for urban and rural household income, reaching $15 \%$, just the maximum capacity to pay of the residents can bear. However, when we view urban residents' per capita disposable income and rural residents per capita net income in 2007, finding urban residents and rural residents' income in different regions of China are different significantly. Shanghai, Beijing, Tianjin's per capita net income of rural residents reached 10222, 9559 and 8752 Yuan, but Gansu, Guizhou, Yunnan's per capita net income of rural residents is only 2328,2374 and 2634 Yuan. Shanghai, Beijing, Tianjin's per capita net income of rural residents is 4 times as many as Gansu, Guizhou, Yunnan's.

Therefore the above model only consider the different fees between urban students and rural students from the whole country, the burden of education fee paid by different area varies largely. So we need to improve the above model. Here, this article introduces some parameter, $\mathrm{Re}_{\mathrm{ij}}$ stands for the number of enrolling new students in ith university of $\mathrm{jth}$ province. $b_{i}$ stands for the proportion of the education fee that university charge occupying the average annual income, $R_{i}$ stands for the proportion between the urban family number of the jth province and rural family number, $U R_{j}$ stands for the disposable income of urban residents from jth province, $\mathrm{CR}_{\mathrm{j}}$ stands for the disposable income of rural residents from $\mathrm{jth}$ province, $\mathrm{UC}_{\mathbf{j}}$ stands for the average annual education fee the urban residents from jth province should pay for, $\mathrm{CC}_{\mathrm{j}}$ stands for the average annual education fee the rural residents from jth province should pay for.

Set up model as follows: $\sum_{j=1}^{31} \operatorname{Re}_{i j} y_{i}=\sum_{j=1}^{31}\left(\frac{R_{j} * U R_{j} * 3 * b_{i}+C R_{j} * 4 b_{i}}{R_{j}+1}\right) * \operatorname{Re}_{i j}$

$$
\left\{\begin{array}{l}
U C_{j}=U R_{j}^{*} 3 b_{i} \\
C C_{j}=C R_{j}^{*} * 4 b_{i} \\
b_{j} \leq 0.15
\end{array}\right.
$$


We use this model to solve the tuition fees of urban students and rural students in all provinces, we get the tuition fees of a national key university in Beijing and an ordinary university in Hebei province in various provinces.

\section{The results of improved model}

We solve the improved model by the means of LINGO11.0 software, the results are as follows:

\begin{tabular}{|l|l|l|l|l|l|l|l|}
\hline \multicolumn{2}{|l|}{ A national key university in Beijing } & \multicolumn{4}{l|}{ An ordinary college in Hebei province } \\
\hline region & $\begin{array}{l}\text { student } \\
\text { intake }\end{array}$ & $\begin{array}{l}\text { Urban } \\
\text { tuition }\end{array}$ & $\begin{array}{l}\text { Rural } \\
\text { tuition }\end{array}$ & region & $\begin{array}{l}\text { student } \\
\text { intake }\end{array}$ & $\begin{array}{l}\text { Urban } \\
\text { tuition }\end{array}$ & $\begin{array}{l}\text { Rural } \\
\text { tuition }\end{array}$ \\
\hline Beijing & 295 & 10225 & 5927 & Beijing & 50 & 9664 & 5602 \\
\hline Hebei & 50 & 5436 & 2662 & Hebei & 1000 & 5138 & 2516 \\
\hline
\end{tabular}

\section{The suggestion to relevant department}

Higher education is important to high-standard person cultivation, innovation ability, the construction of harmonious society. But in present period of Chinese economic development, the unbalance of economic development and the unequal of residential income consist in our country to large extent. How to definite the higher education fee should be based on the payment of resident and the guarantee of fair education. In order to offer enough education funds and make large number of rural children $t$ to attend the university. in other words, to make the proportion between higher education fee and common rural family income not too high, we make few suggestions as follow:

(1) The university that rank former should charge relatively higher because the better universities` cultivation fee, the location advantage, the classification of school and the personal profit after graduation are relatively excellent. According to the principle that huge profit needs huge investment, acquiring high fee is reasonable. For example, Peking University which ranks first should charge higher than the other ordinary Universities.

(2) Each university should distinguish the rural children and the urban children to charge differently. Trough the model we can make preferential to rural children. But the payment of urban family is relatively strong. So we use the payment of urban family to make up for the shortage of rural family income, which involve the question that whether it reasonable or not. Because citizens enjoy some preferential condition in the unbalance of Chinese economic development, it can be accepted that difference consists in the higher education fee.

(3) Based on the different amounts shared by urban and country and the difference in each area, higher education fee should be fixed respectively according to different area. From the model, it can be found that the difference in area can be improved by the economic development (GDP per head levels) of district where students come from,, which makes students from different provinces pay for their fee based on the local actual economic condition.

(4)Through the model we build about 606 universities from the whole country, we can judge a school whether its fee are reasonable and offer the theoretical support to the reform of each school's education fee.

\section{References}

2007 National Higher Education Admissions Guide aggregate admission schem. http://edu.qq.com/zt/2007/2007zsjz/index.htm. September 21st 2008

China Statistical Yearbook of the funding for education(2004-2008). Beijing:China Statistics Press. (in Chinese)

China Statistical Yearbook. (2008). Beijing: China Statistics Press. (in Chinese)

Li Z., Xiao H., et al. (2005). Fuzzy optimization method in the production of decision-making applications. Journal of Southwest University for Nationalities, 31(5),701-704. (in Chinese)

The people Republic of China National Bureau of Statistics(2008). Beijing:China Statistics Press. (in Chinese)

Xie J. and Liu C. (2000). Fuzzy Math Methods and Applications (2nd edition). Wuhan: Huazhong University of Science and Technology Press. (in Chinese)

Xie J.and Xue Y. (2005). Optimize Modeling and LINDO / LINGO software. Beijing: Tsinghua University Press. (in Chinese)

$\mathrm{Xu}$ Y. (2003). The index scale degrees in important research. Journal of Textile Universities basic science, 16(2), 138-140. (in Chinese)

Zhao D., Cai Y., Feng Y., et al. (2008). 2008 Chinese University of evaluation reports. Chinese Higher Education Evaluation. the first phase. (in Chinese) 